\title{
KAP study regarding ill effects of smoking over the health of people particularly oro-dental health and their prevention
}

\author{
DR RIAZ GUL ${ }^{1,}$ DR ADIL ZARIF ${ }^{1}$, DR HIRA GUL \\ COMMUNITY MEDICINE DEPARTMENT, NWSM PESHAWAR.
}

\begin{abstract}
S
The effects of smoking on human health are serious and in many cases, deadly. There are approximately 4000 chemicals in cigarettes, hundreds of which are toxic. The ingredients in cigarettes affect everything from the internal functioning of organs to the efficiency of the body's immune system; the effects of cigarette smoking are destructive and widespread. All forms of tobacco including cigars, smokeless tobacco, and huka pose dental health concerns

OBJECTNES:
\end{abstract}

To Assess the knowedge/awareness, attitude and practices (KAP) of people about adverse effects of smoking on their health particularly oro-dental health

\section{METHODOLOGY:}

The study was conducted in two teaching hospital of Peshawar i.e. KCD (Khyber college of dentistry and SBDC (Sardar begum dental college).it was a cross sectional descriptive study carried out over400 patients who attended the OPD of these hospitals for some reasons. Approval of the study was taken from the ethical committees of both the hospitals. Non probability sampling technique was adopted for the study. All relevant information about the study was gathered with the help of semi structured questionnaire. Purpose of the study was explained to the patients. The study was conducted from May 2016 to November 2016. Patients with systemic diseases that could affect orodental health were excluded from the study. Data was presented in the form of tables and graphs.

\section{RESULTS:}

According to their dentist $52 \%$ of study patients had adverse oral hygiene. About $74.5 \%$ smokers were aware of adverse effects of smoking. 55\% of the people who smoke cigarette are 21-30 years of age. $26.5 \%$ people smoked 1-3 times a day. . In a significant number of patients $41 \%$ people started smoking because of peer pressure. Mass media had a significant role in developing this habit. About $74.5 \%$ are aware of adverse effects of smoking and they consider that it causes bad effects on respiratory system and oral hygiene. Most of the smokers use tooth paste to get rid of bad breath. About 59\% people visited dentist only when some oro-dental problem arises. According to dentist $39.5 \%$ of smokers have adverse oral health status.

\section{CONCLUSION:}

Despite of knowledge of adverse effects of smoking and complaining of bad breath and other conditions related to oro-dental hygiene, majority of them were engaged in regular smoking and they are still satisfied from their oral health ,

KEY WORDS: Oro dental hygiene, adverse Oral health,

\section{INTRODUCTION}

Smoking is a practice where a substance, most commonly tobacco, is burned and the smoke

\begin{tabular}{|c|}
\hline Correspondence \\
Prof. Dr. Riaz Gul \\
Head Department of Community \\
Medicine Northwest \\
raizgul_70@yahoo.com \\
Cell\#0345-9386866 \\
\hline
\end{tabular}
absorbed or inhaled. This is primarily done as a form of recreational drug use, as combustion releases the active substances in drugs such as nicotine and makes them available for absorption through the lungs.

https://doi.org/10.37762/jgmds.4-2.20 
IGMDS

Smoking is a greater cause of death and disability than any single disease. Despite of great number of morbidity and mortality caused by smoking still a large number of people in the world smoke one way other ${ }^{2}$. Most people who smoke so because they can't stop. Nicotine is a highly addictive substance that makes people feel energized and alert. ${ }^{3}$ Tobacco advertising also has a big influence on why people smoke. For years, the industry has focused on making smoking glamorous through advertising in movies, television, and billboards. Smoking produces a feeling of satisfaction that's difficult to give up ${ }^{4}$. Smoking is a social activity as well. Many people who smoke do so as way to start conversations and interact at parties or in social gatherings.. This is known as "social smoking" and it usually involves alcohol as a complement ${ }^{5}$. Many teenagers start smoking due to peer pressure. They may also smoke to feel more mature or as a form of rebellion against parental authority ${ }^{6}$. It has been proved that children are also more likely to smoke if their parents do. According to $\mathrm{WHO}$ figures, it is responsible for approximately five million deaths worldwide every year. Tobacco smoking is a known or probable case of approximately 25 diseases, and even the WHO says that its impact on world health is not fully assessed ${ }^{7}$. Studies conducted in UK show that smokers in their 30 s and 40 s are five times more likely to have a heart attack than nonsmokers $^{8}$. If you smoke for a lifetime, there is a $50 \%$ chance that your eventual death will be smoking-related-half of all these deaths will be in middle age ${ }^{9}$. Smoking also increases the risk of having a stroke. Another primary health risk associated with smoking is lung cancer, which kills more than 20,000 people in the UK every year ${ }^{10}$. Smoking also increases the risk of oral, uterine, liver, kidney, bladder, stomach and cervical cancers, and leukemia ${ }^{11}$. Smoking adversely affects the reproductive system, especially in women. Men experience lower sperm count, more abnormal sperm with decreased motility ${ }^{12}$. Smoking in pregnancy greatly increases the risk of miscarriage, is associated with lower birth weight babies, and inhibited child development ${ }^{13}$. The WHO expects the worldwide heath toll to reach 10 million, causing $17.7 \%$ of all deaths in developed countries by the year 2020. There are believed to be 1.1 billion smokers in the world, 800 million of them in developing countries ${ }^{14}$. Apart from having adverse effects of smoking on our general health, smoking also has very adverse effects upon our dental health and is responsible for many oro dental problems. Cigarettes aren't the only products to blame. All forms of tobacco, including cigar, smokeless tobacco and hoka water pipes, pose dental health concerns ${ }^{15}$. Chronic persistent smokers are more prone to develop the following oro dental problems more frequently as compared to non-smokers.

Persistent bad breath, discolored teeth, An increase of calculus (tartar) build-up, periodontal (gum and cone) disease that may progress more quickly and be more severe than in non-smokers, jaw bone loss, shifting teeth, oral cancer, mouth sores, root caries (cavities), sinusitis, hairy tongue, smokers lip (like a burn), Altered sense of taste and smell, Delayed wound healing ${ }^{16}$. As many as $40 \%$ men and $8 \%$ women in Pakistan smoke regularly. While tobacco use is declining in most other countries of the world, sadly it is on the rise in Pakistan. If we don't take any action, the current global death toll of 5 million per year from tobacco use will increase to 10 million per year by 2025 . In Pakistan, estimated 100,000 people die every year form tobacco related diseases ${ }^{17}$.In response to intense pressure and lobbying of national and international organizations, the government of Pakistan has changed the health warning from "smoking is injurious to health-ministry of Health". To "smoking causes cancer and heart diseases-ministry of health" and now it is at more prominent place on cigarette packet- both in national language (urdu) and English ${ }^{18}$. The solution to the problem is not just maintaining good oral hygiene but to get health professional motivated to support and assist you not only in creating awareness among the people to change their attitude but also to adopt healthy practices in their routine life. ${ }^{19}$ Men and women of all ages experience major and immediate health benefits when they quit smoking. Ex-smokers have a decreased risk of heart disease, respiratory illnesses, strokes and many cancers. In fact, after 15 years, an ex-smokers risk of death is similar to that of a person who has never smoked ${ }^{20}$. 
Quitting will have a significant, positive impact on oral health as well, reducing the rate and incidence of gum disease, oral cancers and bone and tooth loss; keeping teeth whiter and allowing sores to heal and disappear ${ }^{21}$ The main purpose of this study was to Assess the knowledge/awareness, attitude and practices of patients about adverse effects of smoking on their health particularly orodental health and to recommend measures for general public to improve their orodental hygiene.

\section{RESULTS:}

Table No: 1

\section{AGE OF SMOKERS}

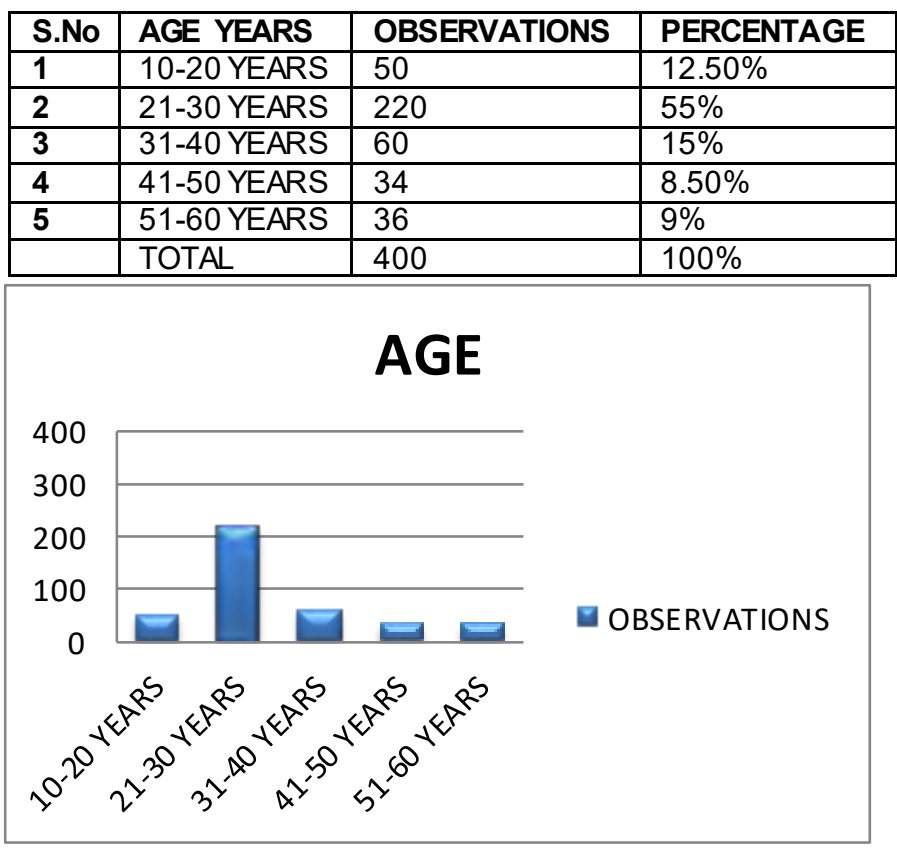

Table and graph 1 indicates numbers of smokers in different age groups. It shows that (12.5\%) of smokers are in 10-20age. 50220 (55\%) of smokers are in 21-30 years of age. $60(15 \%)$ are in 3140 years age group. 36 (9\%) smokers came in range of $51-60$ years of age while $34(8.5 \%)$ of people are 41-50 years of age.

\section{PRODUCTSUSED FOR SMOKING}

Table No:2

\begin{tabular}{|l|l|l|l|}
\hline S.No & $\begin{array}{c}\text { PRODUCTS USED } \\
\text { FOR SMOKING }\end{array}$ & OBSERVATIONS & PERCENTAGE \\
\hline $\mathbf{1}$ & CIGARETTE & 352 & $88 \%$ \\
\hline $\mathbf{2}$ & HUKA & 24 & $6 \%$ \\
\hline $\mathbf{3}$ & CIGARETTE & 8 & $2 \%$ \\
\hline $\mathbf{4}$ & OTHERS & 16 & $4 \%$ \\
\hline & TOTAL & 400 & $100 \%$ \\
\hline
\end{tabular}


KAP STUDY REGARDING ILL EFFECT OF SMOKING OVER THE HEALTH OF PEOPLE PARTICULARLY ORO-DENTAL HEALTH AND THER PREVENTION

IGMDS

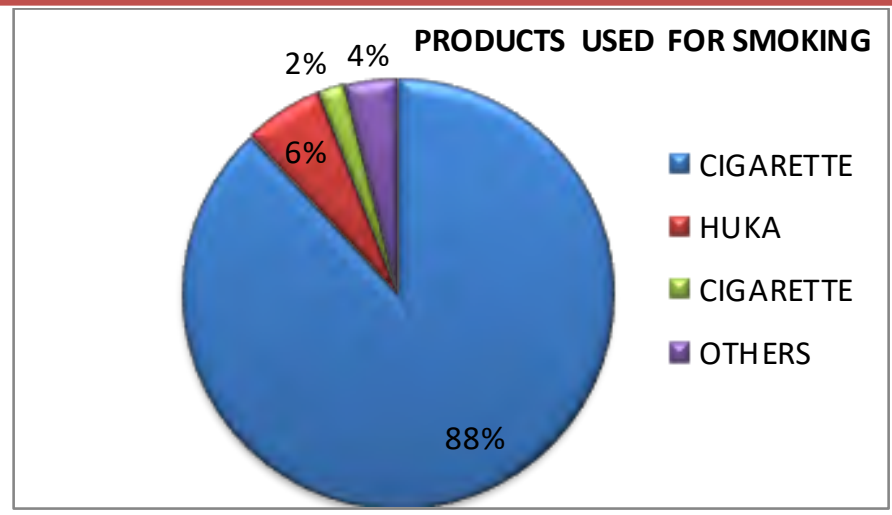

Table and graph 2 shows that 352 (88\%) of people smoke cigrate, 24(6\%) people smoke huka, $8(2 \%)$ people smoke cigar, $16(4 \%)$ people have other smoking method

\section{NUMBER OF TIMES SMOKING DONE EACH DAY}

Table: No: 3

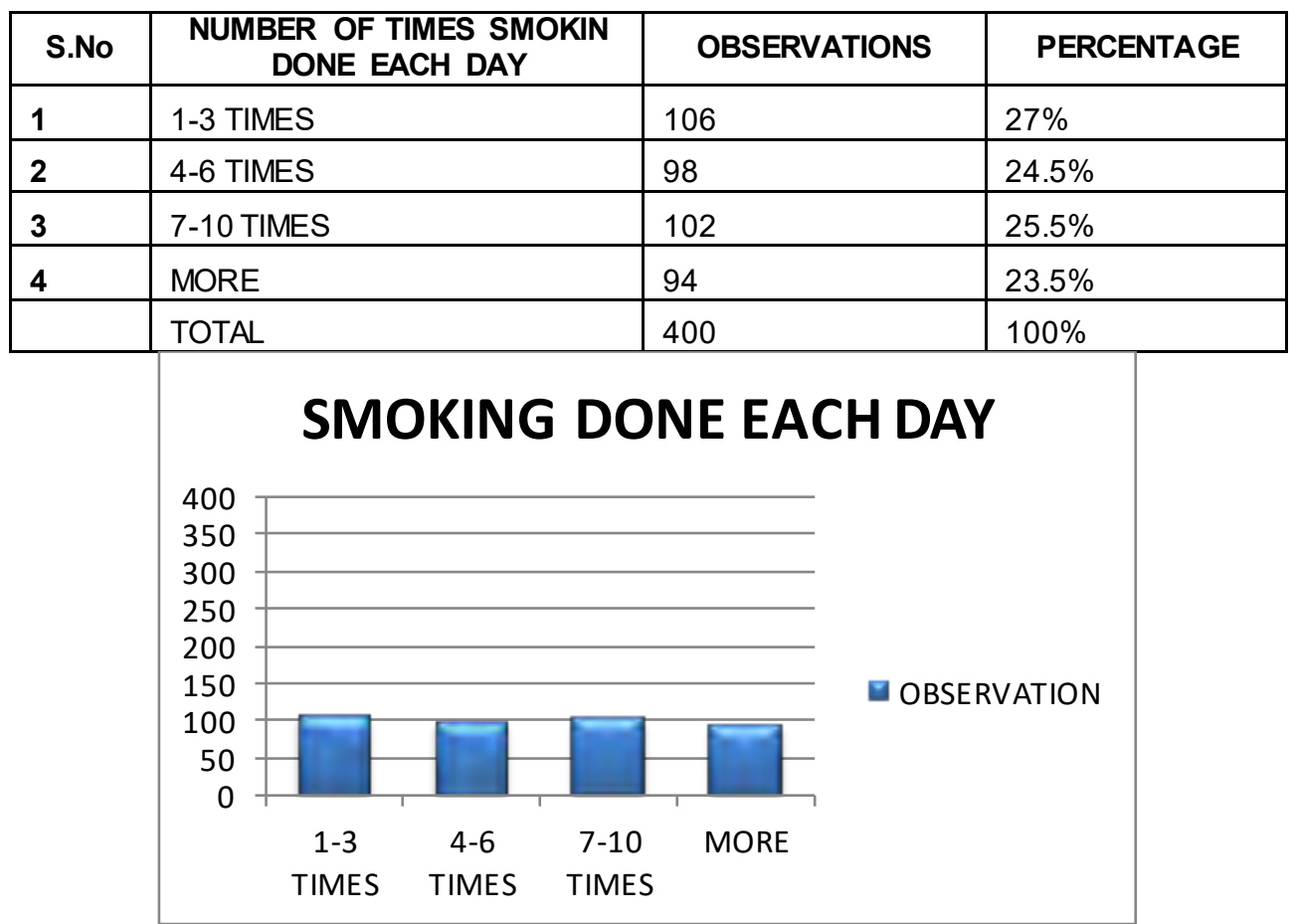

Table and graph 3 shows that 106 (26.5\%) people smoke 1-3 times a day.102 (25\%) people smoke 7-10 times a day. 98 (24.5\%) people smoke 4-6 times a day, while 94 (23.5\%) people smoke more than 10 times a day. 
KAP STUDY REGARDING ILL EFFECT OF SMOKING OVER THE HEALTH OF PEOPLE PARTICULARLY ORO-DENTAL HEALTH AND THER PREVENTION

IGMDS

\section{REASON FOR STARTING SMOKING}

Table No: 4

\begin{tabular}{|l|l|l|l|}
\hline S.No & \multicolumn{1}{|c|}{$\begin{array}{c}\text { REASON FOR STARTING } \\
\text { SMOKING }\end{array}$} & OBSERVATIONS & PERCENTAGE \\
\hline $\mathbf{1}$ & $\begin{array}{l}\text { PARENTAL } \\
\text { INFLUENCE/ELDER } \\
\text { SIBLINGS }\end{array}$ & 6 & $1.50 \%$ \\
\hline $\mathbf{2}$ & $\begin{array}{l}\text { FRIENDS/PEER } \\
\text { PRESSURE }\end{array}$ & 164 & $41 \%$ \\
\hline $\mathbf{3}$ & ADVERTISEMENT & 62 & $15.50 \%$ \\
\hline $\mathbf{4}$ & STRESS/DEPRESSION & 136 & $34 \%$ \\
\hline $\mathbf{5}$ & OTHERS & 32 & $8 \%$ \\
\hline & TOTAL & 400 & $100 \%$ \\
\hline
\end{tabular}

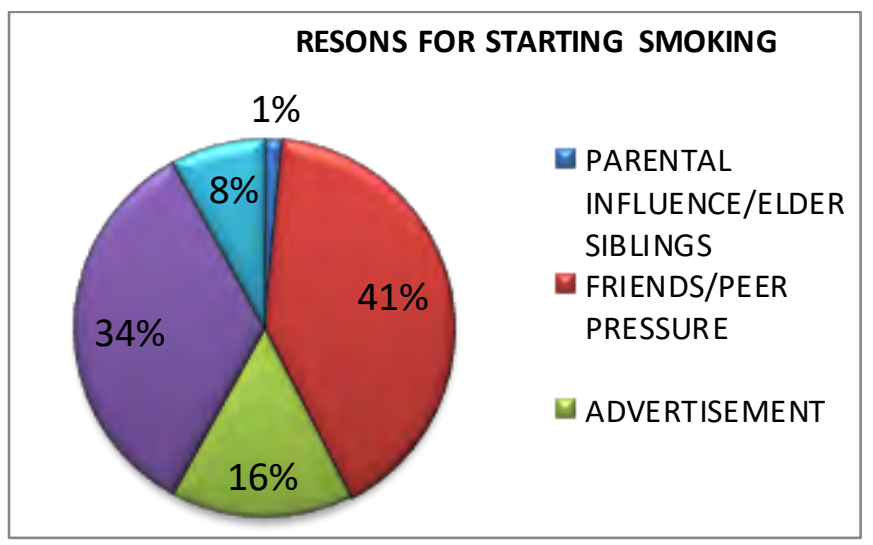

Table and graph 4 shows that how people started smoking. 164 (41\%) started to smoke because of peer pressure, $136(34 \%)$ started smoking because of some stress. $62(15.5 \%)$ were influenced by advertisements, $32(8 \%)$ started because of other reasons while $6(1.5 \%)$ started because of parental influence

\section{DURATION OF SMOKING}

Table No: 5

\begin{tabular}{|l|l|r|r|}
\hline S.No & DURATION OF SMOKING & OBSERVATIONS & PERCENTAGE \\
\hline $\mathbf{1}$ & $1-5$ YEARS & 196 & $49 \%$ \\
\hline $\mathbf{2}$ & $6-10$ YEARS & 124 & $31 \%$ \\
\hline $\mathbf{3}$ & $11-15$ YEARS & 42 & $10.50 \%$ \\
\hline $\mathbf{4}$ & $16-20$ YEARS & 38 & $9.50 \%$ \\
\hline & TOTAL & 400 & $100 \%$ \\
\hline
\end{tabular}




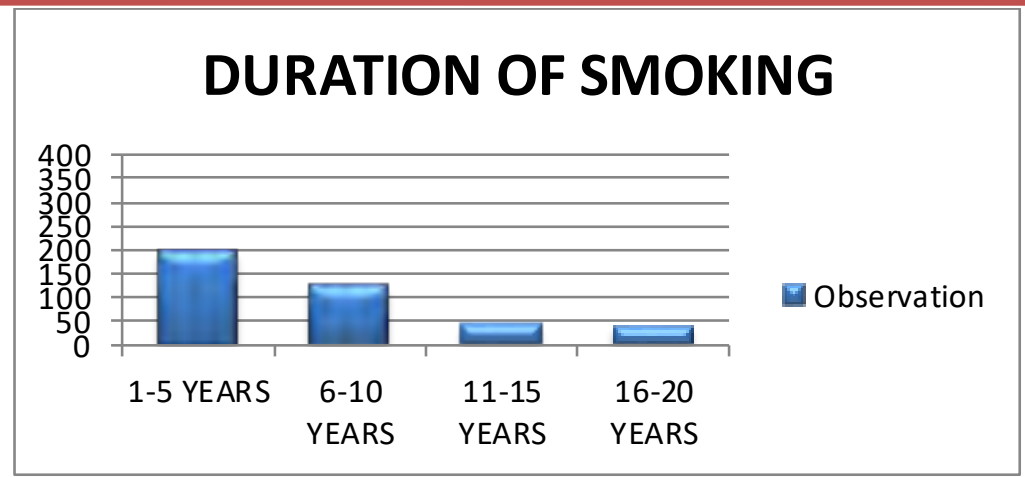

Table and graph 5 depicts duration of smoking. 196 (49\%) people smoke for the last 1-5 years. $124(31 \%)$ for $6-10$ years. $42(10.5 \%)$ for $11-15$ years. $38(9.50 \%)$ are smoking from last 16-20 years.

\section{TYPES OF SMOKING}

Table No: 6

\begin{tabular}{|l|l|l|l|}
\hline S.No & TYPES OF SMOKING & OBSERVATIONS & PERCENTAGE \\
\hline $\mathbf{1}$ & CONTINUOUS & 164 & $41 \%$ \\
\hline $\mathbf{2}$ & NON CONTINUOUS & 236 & $59 \%$ \\
\hline & TOTAL & 400 & $100 \%$ \\
\hline
\end{tabular}

\section{TYPES OF SMOKING}

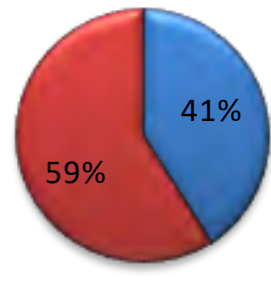

\section{$\square$ CONTINU OUS}

NON-CONTINUOUS

Table and graph 6 depicts number of continuous and non- continuous smokers. 236 (59\%) were non-continuous while 164 (41\%) were continuous

\section{AWARENESS ABOUT BAD EFFECTS OF SMOKING GENERAL HEALTH}

Table No: 7

\begin{tabular}{|l|l|l|l|}
\hline S.No & $\begin{array}{c}\text { AWARENESS REGARDING BAD } \\
\text { EFFETS OF SMOKING ON } \\
\text { ORAL HEALTH }\end{array}$ & OBSERVATIONS & PERCENTAGE \\
\hline $\mathbf{1}$ & YES & 238 & $59.50 \%$ \\
\hline $\mathbf{2}$ & NO & 162 & $40.50 \%$ \\
\hline & TOTAL & 400 & $100 \%$ \\
\hline
\end{tabular}


KAP STUDY REGARDING ILL EFFECT OF SMOKING OVER THE HEALTH OF PEOPLE PARTICULARLY ORO-DENTAL HEALTH AND THER PREVENTION

IGMDS

Table and graph 7 depicts no of people aware or not aware of bad effects of smoking. 298 $(74.5 \%)$ were aware of bad effects of smoking, while $102(25.5 \%)$ were not aware

BAD EFFECTS OF SMOKING ON ORAL HEALTH

Table No: 08

\begin{tabular}{|l|l|l|l|}
\hline S.No & $\begin{array}{c}\text { BAD EFFECTS OF SMOKING } \\
\text { ON ORAL HELALTH }\end{array}$ & OBSERVATIONS & PERCENTAGE \\
\hline $\mathbf{1}$ & BAD BREATH & 150 & $37.50 \%$ \\
\hline $\mathbf{2}$ & INCREASED CALCULUS & 58 & $14.5 \%$ \\
\hline $\mathbf{3}$ & DISCOLORATION OF THEETH & 70 & $17.5 \%$ \\
\hline $\mathbf{4}$ & TOOTH FALL & 32 & $8.0 \%$ \\
\hline $\mathbf{5}$ & ORAL ULCERS/MOUTH SORES & 48 & $12.0 \%$ \\
\hline $\mathbf{6}$ & ROOT CARRIES & 24 & $6.00 \%$ \\
\hline $\mathbf{7}$ & $\begin{array}{l}\text { ALTER SENSE OF TASTE AND } \\
\text { SMELL }\end{array}$ & 14 & $3.50 \%$ \\
\hline $\mathbf{8}$ & OTHERS & 4 & $1.0 \%$ \\
\hline & TOTAL & 400 & $100 \%$ \\
\hline
\end{tabular}

Note: Subjects Were Given the Option To Choose More Than One Effects

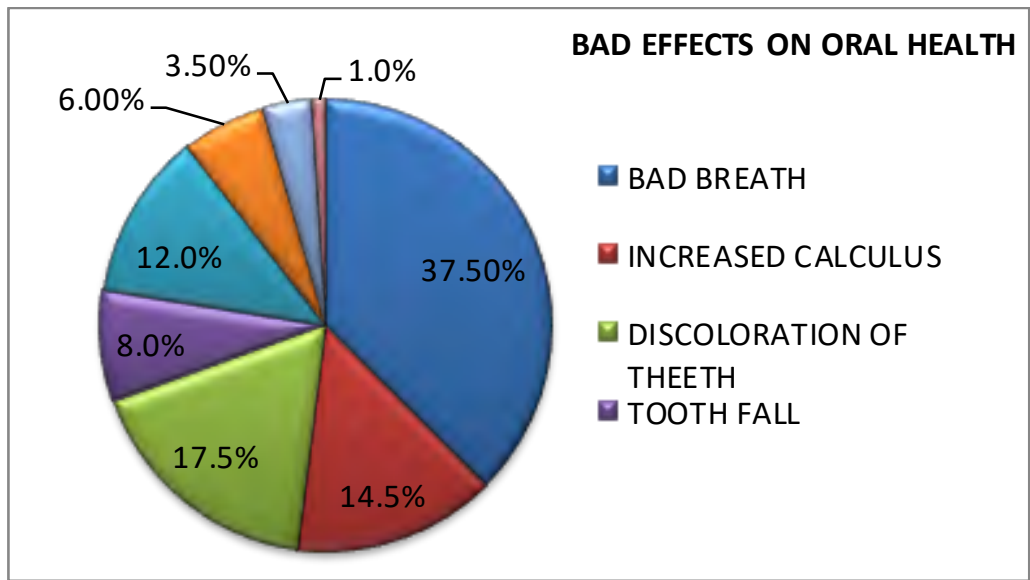

Table and graph 8 shows the effects on oral health noticed by the smokers. 150(37.5\%) complains of bad breath, $58(14.5 \%)$ people increase calculus $70(17.5 \%)$ people complains of dislocation of teeth, $32(8 \%)$ people complains tooth fall, $48(12 \%)$ complains of oral ulcers, $24(6 \%)$ complains of 
KAP STUDY REGARDING ILL EFFECT OF SMOKING OVER THE HEALTH OF PEOPLE PARTICULARLY ORO-DENTAL HEALTH AND THER PREVENTION

IGMDS

root carries, $14(3.5 \%)$ complains of altered sense of taste and smell and $4(1.0 \%)$ have complains of different other effects.

SOURCE OF INFORMATION REGARDIN THE BAD EFFECTS OF SMOKING ON GENRAL HEALTH

Table No: 09

\begin{tabular}{|l|l|l|l|}
\hline S.No & $\begin{array}{c}\text { SOURCE OF INFORMATION } \\
\text { REGARDIN THE BAD EFFECTS } \\
\text { OF SMOKING ON GENRAL }\end{array}$ & OBSERVATIONS & PERCENTAGE \\
\hline $\mathbf{1}$ & MASS MEDIA & 166 & $41.50 \%$ \\
\hline $\mathbf{2}$ & COMMUNITY & 108 & $27.00 \%$ \\
\hline $\mathbf{3}$ & FRIENDS & 68 & $17.00 \%$ \\
\hline $\mathbf{4}$ & DENTIST & 58 & $14.50 \%$ \\
\hline & TOTAL & 400 & $100.00 \%$ \\
\hline
\end{tabular}

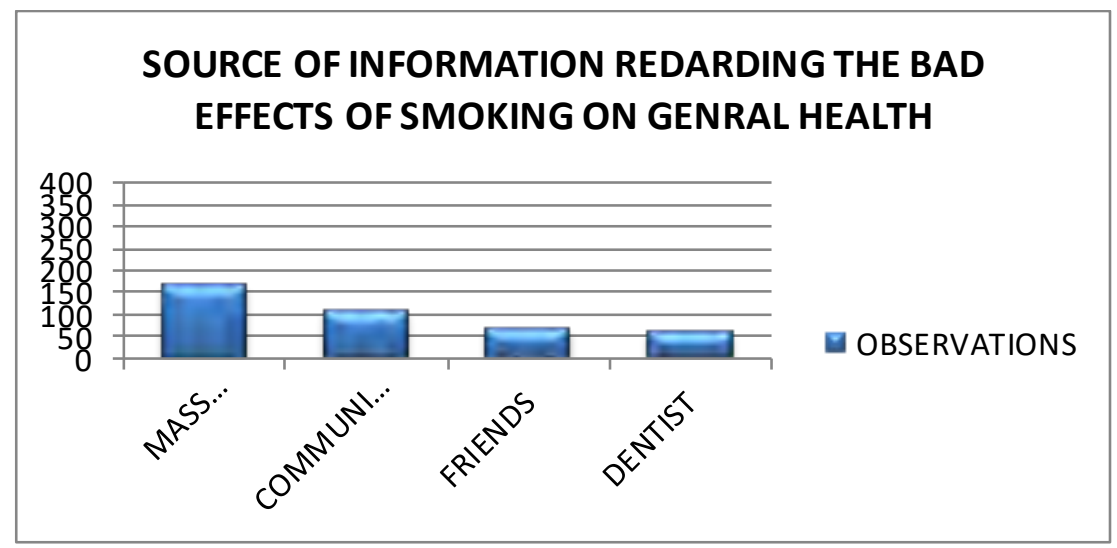

Table and graph 9 indicates different sources of information regarding effect of smoking. $166(41.5 \%)$ got information form mass media108 (27\%) got information from community, 68(17\%) got information from friends while $58(14.5 \%)$ form dentist

PRODUCTS USED FOR GETTING RID OF BAD BREATH Table No: 10

\begin{tabular}{|l|l|l|l|}
\hline S.No & $\begin{array}{c}\text { PRODUCTS USED FOR GETTING } \\
\text { RID OF BAD BREATH }\end{array}$ & OBSERVATIONS & PERCENTAGE \\
\hline $\mathbf{1}$ & TOOTH PASTE & 150 & $38 \%$ \\
\hline $\mathbf{2}$ & MOUTH FRESHENER & 102 & $25.50 \%$ \\
\hline $\mathbf{3}$ & MASWAK & 70 & $17.50 \%$ \\
\hline $\mathbf{4}$ & MOUTHWASH & 48 & $12 \%$ \\
\hline $\mathbf{5}$ & OTHERS & 30 & $7.50 \%$ \\
\hline & TOTAL & 400 & $100 \%$ \\
\hline
\end{tabular}


IGMDS

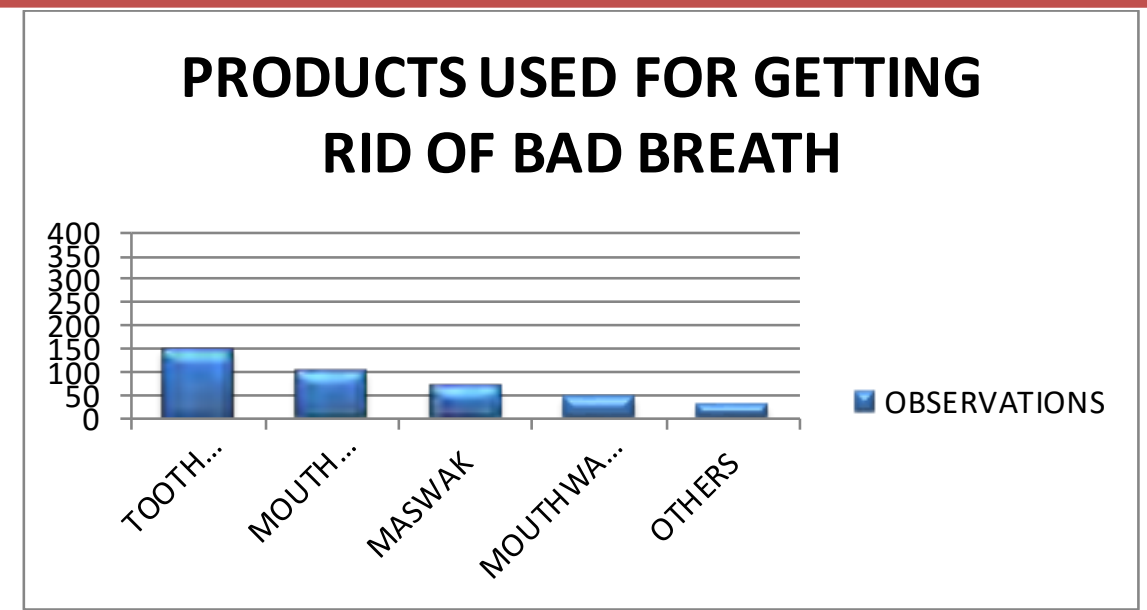

Table and graph 10 illustrates that what are the products used for getting rid of bad breath. 150(38\%) people use toothpaste. 102(25.5\%) use mouth freshener. 70(17.5\%) people use maswak. 48(12\%) smoker use mouth wash, while $30(7.50 \%)$ uses other remedies to get rid of bad breath.

DENTAL VISITS IN A YEAR

Table No: 11

\begin{tabular}{|l|l|l|l|}
\hline $\mathbf{S . N O}$ & DENTAL VISITS IN A YEAR & OBSERVATIONS & PERCENTAGE \\
\hline $\mathbf{1}$ & TWICE A MONTH & 14 & $3.5 \%$ \\
\hline $\mathbf{2}$ & ONCE A MONTH & 14 & $3.5 \%$ \\
\hline $\mathbf{3}$ & EVERY 3 MONTHS & 20 & $5 \%$ \\
\hline $\mathbf{4}$ & EVERY 6 MONTHS & 28 & $7 \%$ \\
\hline $\mathbf{5}$ & WHEN PROBLEM ARISES & 242 & $60.5 \%$ \\
\hline $\mathbf{6}$ & NONE & 82 & $20.5 \%$ \\
\hline & TOTAL & 400 & $100 \%$ \\
\hline
\end{tabular}

DENTAL VISITS IN A YEAR

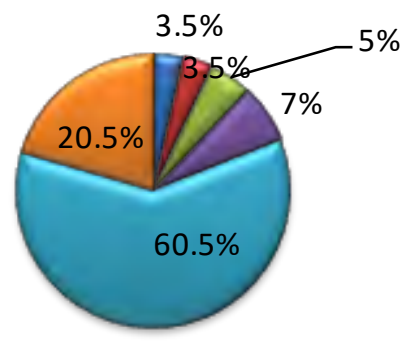

- TWICE A MONTH

- ONCE A MONTH 
IGMDS

Table and graph 11 shows number of dental visits by smokers in a year. 14 (3.5\%) visit dentist twice a month. 14 (3.5\% visit dentist once a month. $20(5 \%)$ visit dentist every 3 months. $28(7 \%)$ visits once every 6 month. $242(60.50 \%)$ visits when problem arises and 82(20.5\%) people never brush their teeth.

DALY BRUHSING

Table No: 12

\begin{tabular}{|l|l|l|l|}
\hline S.No & DAILY BRUSING & OBSERVATIONS & PERCENTAGE \\
\hline $\mathbf{1}$ & ONCE A DAY & 186 & $46.5 \%$ \\
\hline $\mathbf{2}$ & TWICE A DAY & 164 & $41 \%$ \\
\hline $\mathbf{3}$ & MORE & 40 & $10 \%$ \\
\hline $\mathbf{4}$ & NONE & 10 & $2.5 \%$ \\
\hline & TOTAL & 400 & $100 \%$ \\
\hline
\end{tabular}

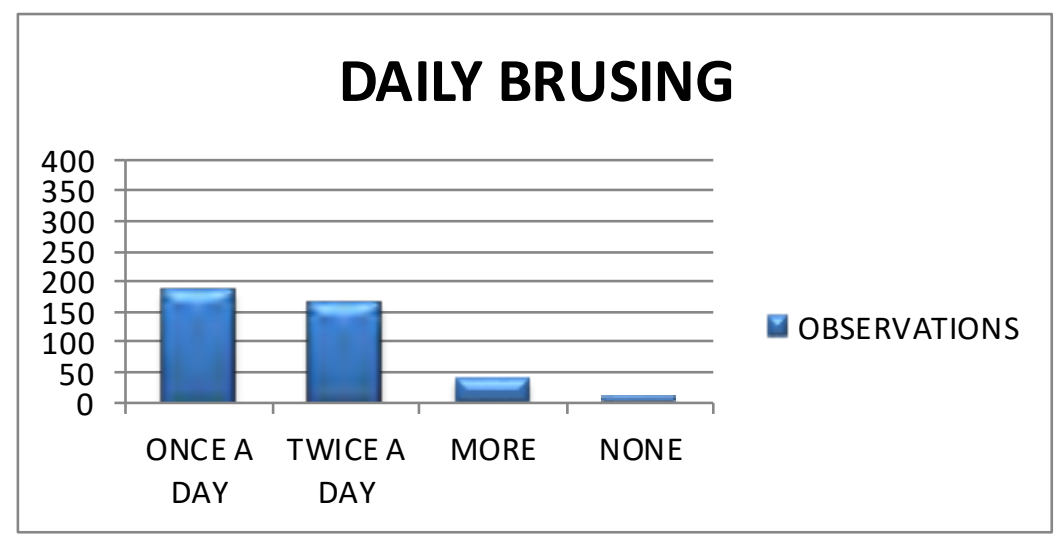

Table and graph 12 shoes number of times people brush daily. 186(46.5) people brush teeth once a day, 164(41\%) brush teeth twice a day 40 (10\%) people brush more than twice a day. 20(10\%) people brush more than twice a day. $10(2.5 \%)$ people never brush their teeth

RODUCT USED FOR BRUSHING

Table No: 13

\begin{tabular}{|l|l|l|l|}
\hline S.No & $\begin{array}{c}\text { PRODUCT USED FOR } \\
\text { BRUSHING }\end{array}$ & OBSERVATIONS & PERCENTAGE \\
\hline $\mathbf{1}$ & TOOTH BRUSH & 270 & $67.50 \%$ \\
\hline $\mathbf{2}$ & MASWAK & 103 & $25.75 \%$ \\
\hline $\mathbf{3}$ & DANDASA & 25 & $6.25 \%$ \\
\hline $\mathbf{4}$ & OTHERS & 2 & $0.50 \%$ \\
\hline & TOTAL & 400 & $100 \%$ \\
\hline
\end{tabular}


IGMDS

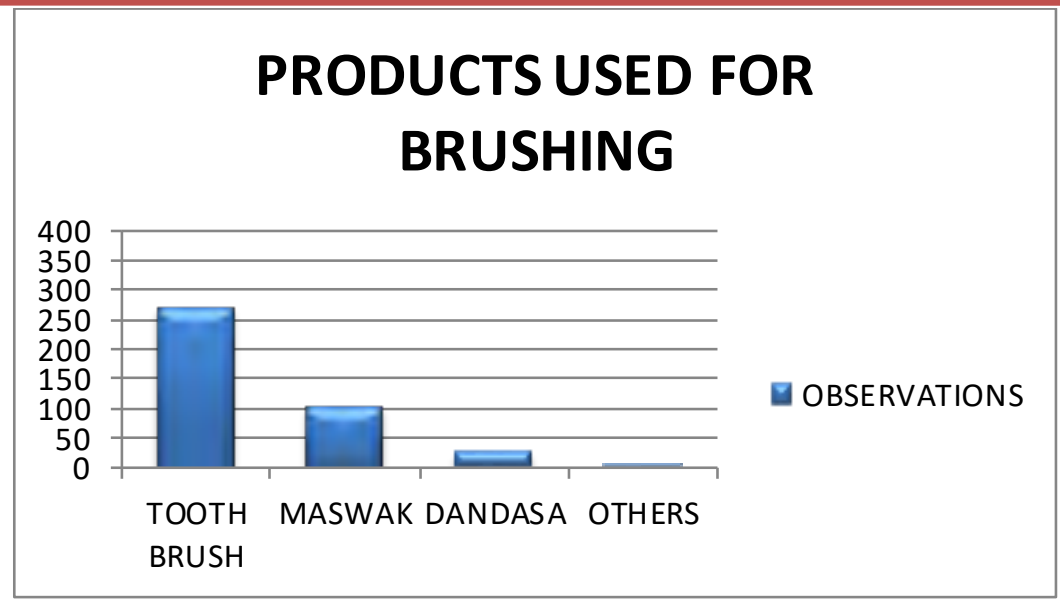

Table and graph 13 shows the product used for brushing. $270(67.50 \%)$ use tooth brush for brushing. 102(25.50\%) use maswak and 25 (6.25\%) use dandasa , while only 2 patients were using other home remedies for cleaning their teeth.

\section{BRAND OF TOOTHPASTE USED}

Table No:14

\begin{tabular}{|l|l|l|l|}
\hline S.No & $\begin{array}{c}\text { BRAND OF } \\
\text { TOOTHPASTE USED }\end{array}$ & OBSERVATIONS & PERCENTAGE \\
\hline $\mathbf{1}$ & COLGATE & 160 & $40 \%$ \\
\hline $\mathbf{2}$ & CLOSEUP & 72 & $18.0 \%$ \\
\hline $\mathbf{3}$ & PEPSODENT & 16 & $4 \%$ \\
\hline $\mathbf{4}$ & MEDICAM & 52 & $13 \%$ \\
\hline $\mathbf{5}$ & OTHERS & 100 & $25 \%$ \\
\hline & TOTAL & 400 & $100 \%$ \\
\hline
\end{tabular}

\section{TOOTHPASTE BRAND}
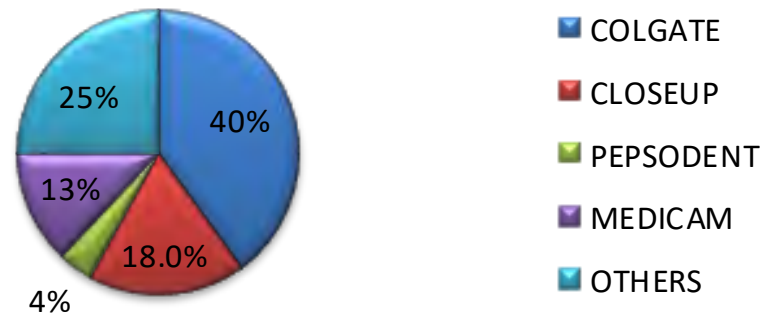

Table and graph 14 shows the brand of tooth paste used mostly. 160 (40\%) people use Colgate. 72(18\%) use Closeup. 52 (13\%) use Medicam while, 16 (4\%) use Pepsodent. 100 (25\%) use other brands. 
KAP STUDY REGARDING ILL EFFECT OF SMOKING OVER THE HEALTH OF PEOPLE PARTICULARLY ORO-DENTAL HEALTH AND THER PREVENTION

IGMDS

KNOWLEDGE REGARDING PROPER WAY OF BRUSHING

Table No: 15

\begin{tabular}{|l|l|l|l|}
\hline S.No & $\begin{array}{c}\text { KNOWLEDGE } \\
\text { REGARDING PROPER } \\
\text { WAY OF BRUSHING }\end{array}$ & OBSERVATIONS & PERCENTAGE \\
\hline $\mathbf{1}$ & YES & 324 & $81 \%$ \\
\hline $\mathbf{2}$ & NO & 76 & $19 \%$ \\
\hline & TOTAL & 400 & $100 \%$ \\
\hline
\end{tabular}

KNOWLEDGE REGARDING PROPER WAY OF BRUSHING

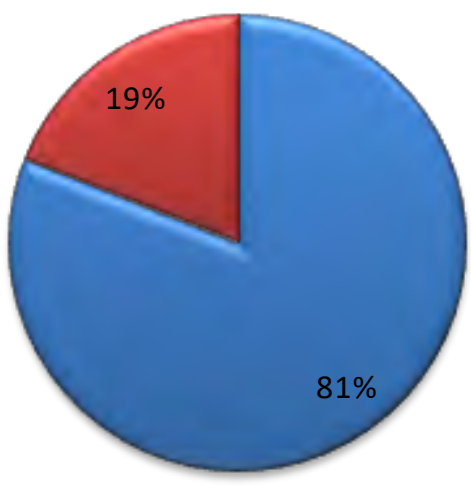

Table and graph 15 shows that how many people know the proper way of brushing. 324 (81\%) know the proper way of brushing. While 76 (19\%) don't know the proper way of brushing.

PRODUCTS USED FOR MAINTANG ORAL HYGIENE

Table No: 16

\begin{tabular}{|c|c|c|c|}
\hline S.No & $\begin{array}{c}\text { PRODUCT USED FOR } \\
\text { MAINTAING ORAL HYGIENE }\end{array}$ & OBSERVATIONS & PERCENTAGE \\
\hline 1 & MOUTH WASH & 240 & $60 \%$ \\
\hline 2 & FLOSS & 36 & $9 \%$ \\
\hline 3 & DANDASA & 64 & $16 \%$ \\
\hline \multirow[t]{2}{*}{4} & OTHER & 60 & $15 \%$ \\
\hline & TOTAL & 400 & $100 \%$ \\
\hline
\end{tabular}


IGMDS

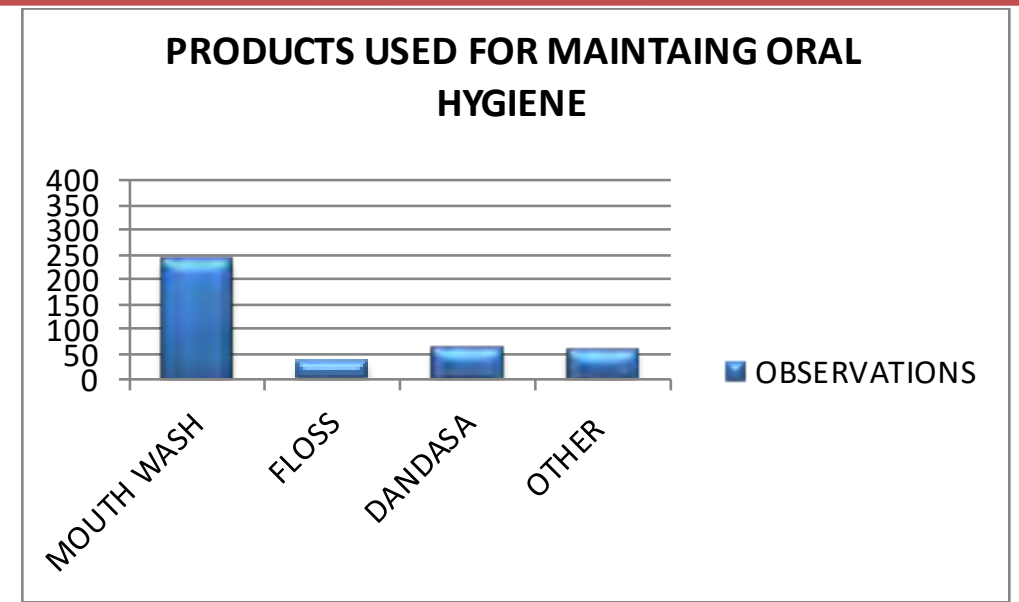

Table and graph 16 shows that what other products are used to maintain oral hygiene. 240 (60\%) use mouthwash. $64(16 \%)$ people use dandasa. $60(15 \%)$ use other products.36(9\%) use floss.

\section{USE OF MEDICINE FOR DENTAL PROBLEMS}

Table No: 17

\begin{tabular}{|l|l|l|l|}
\hline S.No & \multicolumn{1}{|c|}{$\begin{array}{c}\text { USE OF MEDICINE FOR DENTAL } \\
\text { PROBLEMS }\end{array}$} & OBSERVATIONS & PERCENTAGE \\
\hline $\mathbf{1}$ & YES & 112 & $28 \%$ \\
\hline $\mathbf{2}$ & NO & 288 & $72 \%$ \\
\hline & TOTAL & 400 & $100 \%$ \\
\hline
\end{tabular}

USE OF MEDICINE FOR DENTAL PROBLEMS

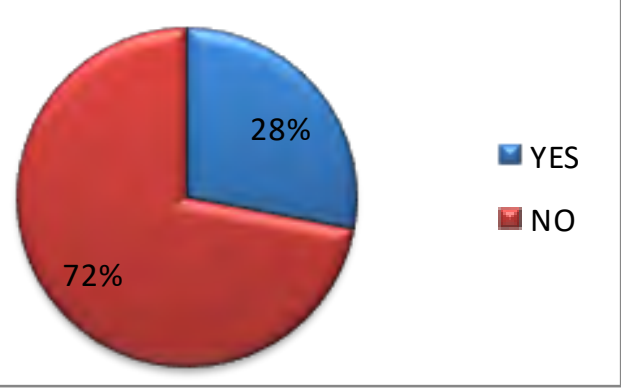

Table and graph 17 shows number of people using or not using medications for dental problem. $112(28.17 \%)$ people are using certain medication while 288 (72\%) people are not suing. 
KAP STUDY REGARDING ILL EFFECT OF SMOKING OVER THE HEALTH OF PEOPLE PARTICULARLY ORO-DENTAL HEALTH AND THER PREVENTION

IGMDS

ORAL HEALTH STATUS ACCCORDING TO DENTIST

Table No: 18

\begin{tabular}{|l|l|r|r|}
\hline S.No & \multicolumn{1}{|c|}{$\begin{array}{c}\text { ORAL HEALTH STATUS } \\
\text { ACCCORDING TO DENTIST }\end{array}$} & OBSERVATIONS & PERCENTAGE \\
\hline $\mathbf{1}$ & BAD & 158 & $39.50 \%$ \\
\hline $\mathbf{2}$ & AVERAGE & 170 & $42.50 \%$ \\
\hline $\mathbf{3}$ & GOOD & 42 & $10.50 \%$ \\
\hline $\mathbf{4}$ & VERY GOOD & 30 & $7.50 \%$ \\
\hline & TOTAL & 400 & $100 \%$ \\
\hline
\end{tabular}

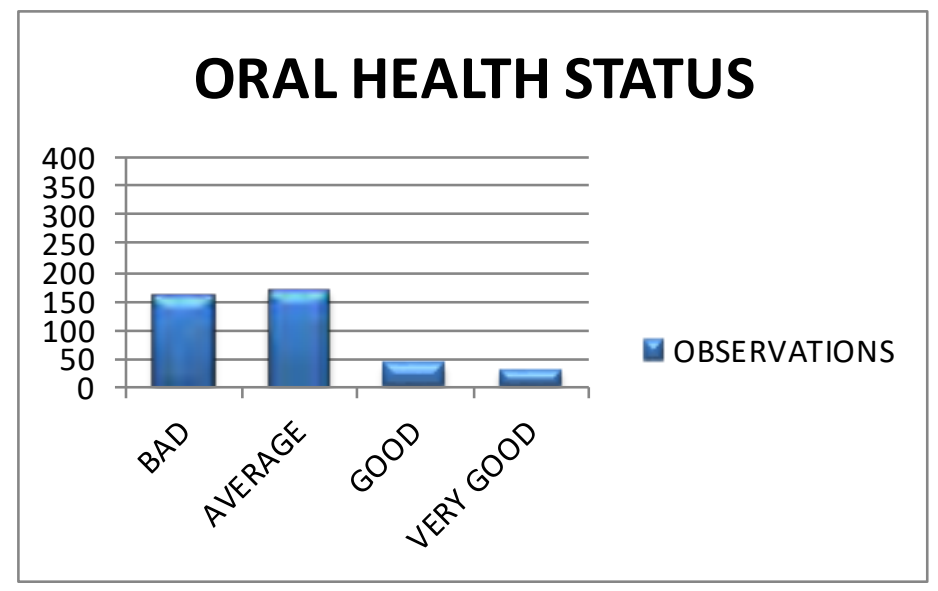

Table and graph 18 indicates the oral health status of subjects according to dentist. 170 (42.5\%) have average health, $158(39.5 \%)$ have bad oral health, $42(10.5 \%$ have good oral health, while only $30(7.5 \%)$ have very good oral health status

\section{REASON OF BAD ORAL HEALTH}

Table No: 19

\begin{tabular}{|l|l|r|r|}
\hline $\mathbf{S}$. No & REASON OF BAD ORAL HEALTH & OBSERVATIONS & PERCENTAGE \\
\hline $\mathbf{1}$ & SMOKING & 212 & $53.00 \%$ \\
\hline $\mathbf{2}$ & FOOD & 61 & $15.25 \%$ \\
\hline $\mathbf{3}$ & ORODENTAL HYGIENE & 81 & $20.25 \%$ \\
\hline $\mathbf{4}$ & OTHERS & 46 & $11.50 \%$ \\
\hline & TOTAL & 400 & $100 \%$ \\
\hline
\end{tabular}

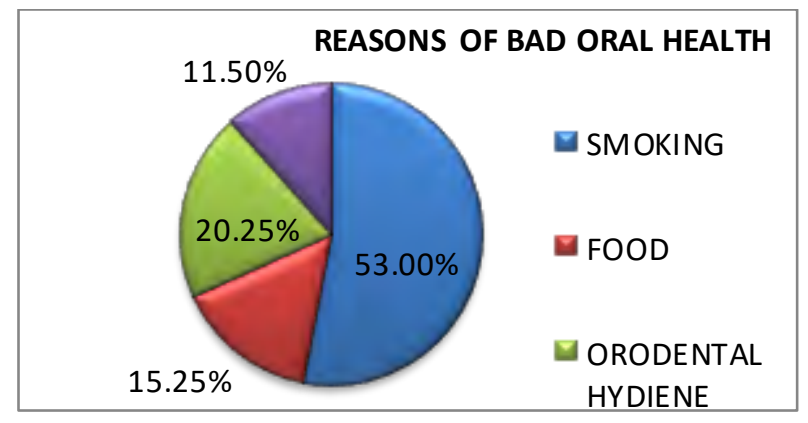


Table and graph 19 shows the reasons for bad oral health, 212(53.00\%) people considered smoking as a cause for their bad oral health, $81(20.25 \%)$ considered poor oro-dental hygiene as a cause, $61(15.25 \%)$ considered food as a cause, while $46(11.50 \%)$ gave other reasons

\section{SLEF SATISFACTION ABOUT ORAL HEALTH}

Table No: 20

\begin{tabular}{|l|l|l|l|}
\hline S.No & $\begin{array}{c}\text { SELF SATISFACTION } \\
\text { ABOUT ORAL HEALTH }\end{array}$ & OBSERVATIONS & PERCENTAGE \\
\hline $\mathbf{1}$ & YES & 296 & $74 \%$ \\
\hline $\mathbf{2}$ & NO & 104 & $26 \%$ \\
\hline & TOTAL & 400 & $100 \%$ \\
\hline
\end{tabular}

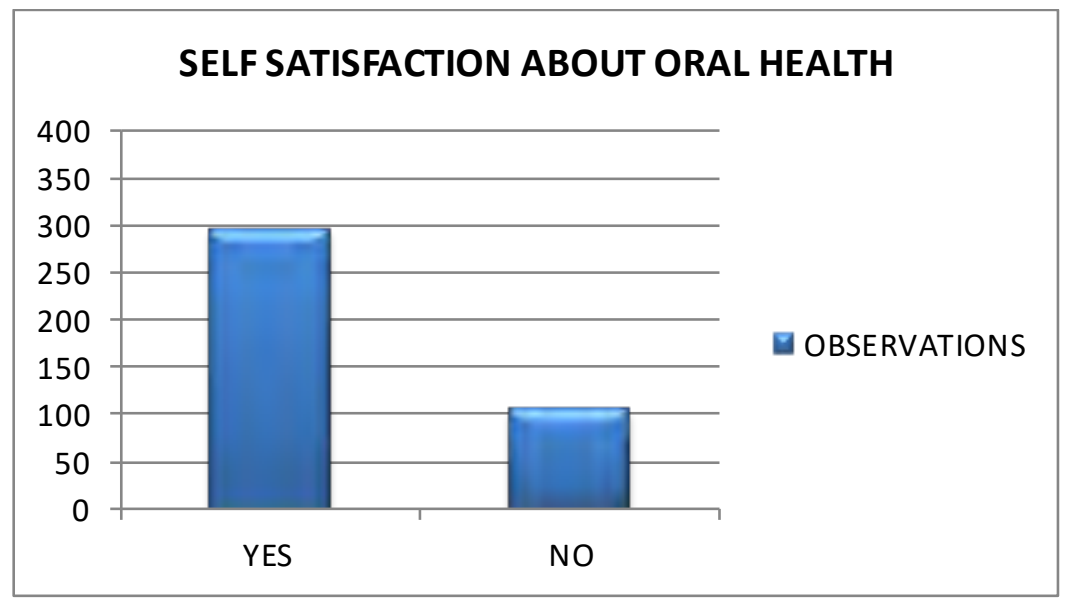

Table and graph 24 shows the no of people satisfied or not satisfied by their oral health. 296 (74\%) are satisfied by their oral health while104 (26\%) are not satisfied by their oral health.

\section{DISCUSSION}

Our results show that majority of the patients visiting the dental OPD were young to middle aged males. The highest prevalence of smoking among males was seen in those aged 21-30 years and majority of them smoke cigarettes. Our study findings are similar to those of a study conducted by Department of International Health; USA Our study also reveals that $88 \%$ of the smokers smoked cigarettes. ${ }^{22}$ While trying to find out the conditions or factors that compel people to smoke, we found that peer pressure is the major cause leading to increased prevalence of smoking. $41 \%$ of the smokers were made to smoke by their friends. $34 \%$ of the smokers started smoking because of stressful life conditions. Advertisement also plays some role but only $8 \%$ of the smokers were influenced by the advertisements, maybe because of the ban imposed on cigarette advertisements by the government. Similar results were almost obtained by other studies conducted where peer pressure and stressful life were found to be the most common factors responsible ${ }^{23}$ We all know that the longer we are exposed to the risk factor more are chances of the disease occurrence. Our study however failed to establish such a relationship between the duration of smoking and its effects. $26.5 \%$ of the smokers smoked $1-3$ times a day whereas $25.5 \%$ smoked $7-10$ times a day, none of the patients were chain smokers. Researchers have proved in their studies the association 
IGMDS

of duration of smoking with different serious diseases like lung cancer. ${ }^{24}$ Surprisingly majority of the smokers coming to the dental OPD for some dental problem were just beginners. $49 \%$ of the smokers were smoking for 1-5 years and yet they were facing the dental problems while those who were smoking for $6-10$ years accounted only $31 \%$ of the smoker patients, similarly those smoking for $11-15$ years accounted $10.5 \%$ smoker patients. In an attempt to find out the knowledge and awareness among smokers regarding the effects of smoking on general health and oral health in particular, we were surprised to find out that majority of the smokers were still smoking in spite of knowing the ill effects of smoking. According to our study $74.5 \%$ of the smokers were aware of ht bad effects of smoking on health, out of which $55 \%$ thought that smoking caused reparatory diseases while $16 \%$ thought that heart was affected by smoking. The same trend has been observed by other researchers in their studies that majority of the smokers continue with this bad habit despite of knowing its adverse effects. ${ }^{25}$ As far as the source of the information regarding the bad effects of smoking is concerned, mass media, whether it is newspaper, television or internet is playing its role in creating awareness among the population. In this regard $34.8 \%$ of the smokers got information through mass media. Here we must not forget that it is also the mass media that in some way is responsible for promoting cigarette smoking as a symbol of status and courage and therefore is contributing to the increased prevalence. Majority of the smokers had problem of bad breath and to overcome this problem $73 \%$ of the smokers used tooth paste, while a few used additional products such as mouth freshener $28.5 \%$ maswak $24.5 \%$ and mouth wash $17 \%$. Here majority of the smokers were using a combination of two or more products. Use of tooth paste and mouth fresheners were commonly used products by majority of people for their oro dental hygiene in results of other studies. ${ }^{26}$ In Pakistan the concept of regular dental visit is yet to be established. Through our study we were able to find out that majority $59.5 \%$ of the smokers visited the dentist only when they had some dental problems while $20.5 \%$ of the smokers had never visited the dentist before. $46.5 \%$ of the smokers brushed once a day while $41 \%$ had the habit of brushing twice daily. $2.5 \%$ of the smokers never bothered to brush. Majority of the smokers brushed their teeth in morning before breakfast. Regarding the knowledge among smokers about the proper way to brush, $81 \%$ of the people said that they were aware of the proper way to brush $80.5 \%$ of the smokers used toothpaste for brushing their teeth and the brand they preferred was Colgate. The increased preference for Colgate may be due to the fact, that our study was conducted in two of the dental hospitals where Colgate has been arranging free dental checkups and free giveaways. Smokers often have dental problems and that is why we asked them whether they were using any medications. About $28 \%$ people used medication for various dental problems and these medicines were usually prescribed by dentists. It is very important to know the oral health status of the smokers according to the dentist. According to the dentist majority of the smokers had an average to bad oral health status. $60.75 \%$ smokers were of the view that smoking was responsible for their poor oral health. Surprisingly, in contradiction to the dentist opinion about their oral health status majority of the smokers were satisfied with their oral health.

\section{CONCLUSION}

After going through our project findings we were able to arrive at a conclusion. According to our study most of the people preferred to smoke cigarette rather than other form of tobacco available. Though most of the people were just beginners i.e., they had been smoking only for a short duration of period still they were encountering dental problems. Most of the people started smoking because of their friends/peer pressure but some other factors like stress, advertisements and parental 
influence also contributed. $74.5 \%$ of people were aware of bad effects of smoking on health like lung cancer, coronary heart disease, bronchitis, stomach problem etc while $25.5 \%$ were unaware. Although many smokers knew the bad effects of smoking on their dental health which includes bad breath, discoloration of teeth and oral ulcers by they still choose to smoke. In our study most of the smokers use toothpaste to get rid of bad breath which is the main problem they were encountering due to smoking, while others use mouth freshener, maswak and dandasa. Majority of the smokers $59.5 \%$ visited dentist only when some dental problem arises. Very few people were found to be having routine checkups. Majority of smokers were using medicine for the oro-dental problems and these medicine were prescribed by the doctor/dentist. According to dentist $39.5 \%$ of the smokers had bad oro-dental hygiene for which the smokers considered smoking as a cause while $42.5 \%$ of the smokers had average oro-dental hygiene. Despite of all the problems these smokers were facing, still majority $74 \%$ were satisfied by their oral health status.

\section{REFERENCES:}

1. Peto R, Lopez AD, Boreham J, Thun M, Heath C Jr. Mortality from tobacco in developed countries: indirect estimation from national vital statistics. Lancet 1992; 339: 1268 -78.

2. Cigarette brand use among adult smokers-United States, 1986. MMWR Morb Mortal Wkly Rep 1990; 39: 665, 671-3.

3. Travis WD, Travis LB, Devesa SS. Lung cancer [published erratum appears in Cancer 1995;15;75:2979]. Cancer 1995 ; 75(1 Suppl) : 191 -202.

4. Shopland DR, Eyre HJ, Pechacek TF. Smoking-attributable cancer mortality in 1991: is lung cancer now the leading cause of death among smokers in the United States? J Natl Cancer Inst $1991 ; 83: 1142-8$.

5. Day GL, Blot WJ, Austin DF, Bernstein L, Greenberg RS, Preston-Martin S, et al. Racial differences in risk of oral and pharyngeal cancer: alcohol, tobacco, and other determinants. J Natl Cancer Inst $1993 ; 85: 465$-73.

6. Gammon MD, Schoenberg JB, Ahsan H, Risch HA, Vaughan TL, Chow WH, et al. Tobacco, alcohol, and socioeconomic status and adenocarcinomas of the esophagus and gastric cardia. J Natl Cancer Inst $1997 ; 89: 1277$-84.

7. Brown LM, Hoover RN, Greenberg RS, Schoenberg JB, Schwartz AG, Swanson GM, et al. Are racial differences in squamous cell esophageal cancer explained by alcohol and tobacco use? J Natl Cancer Inst $1994 ; 86: 1340$-5.

8. Giovino GA, Henningfield JE, Tomar SL, Escobedo LG, Slade J. Epidemiology of tobacco use and dependence. Epidemiol Rev $1995 ; 17: 48-65$.

9. Husten CG, Shelton DM, Chrismon JH, Lin YC, Mowery P, Powell FA. Cigarette smoking and smoking cessation among older adults: United States, 1965-94. Tob Control $1997 ; 6$ : $175-80$. 
KAP STUDY REGARDING ILL EFFECT OF SMOKING OVER THE HEALTH OF PEOPLE PARTICULARLY ORO-DENTAL HEALTH AND THER PREVENTION

IGMDS

10. Tobacco use among high school students_United States, 1997. MMWR Morb Mortal Wkly Rep 1998 ; 47: 229 -33.

11. Cigarette smoking among adults-United States, 1992, and changes in the definition of current cigarette smoking [published erratum appears in MMWR Morb Mortal Wkly Rep 1994;43:801-3]. MMWR Morb Mortal Wkly Rep 1994 ; 43 : 342 -6.

12. Klevens RM, Giovino GA, Peddicord JP, Nelson DE, Mowery P, Grummer-Strawn L. The association between veteran status and cigarette-smoking behaviors. Am J Prev Med 1995 ; $11: 245-50$.

13. Zhu BP, Giovino GA, Mowery PD, Eriksen MP. The relationship between cigarette smoking and education revisited: implications for categorizing persons' educational status [published erratum appears in Am J Public Health 1997;87:168]. Am J Public Health 1996 ; 86 : 1582 $-9$.

14. Flint AJ, Novotny TE. Poverty status and cigarette smoking prevalence and cessation in the United States, 1983-1993: the independent risk of being poor. Tob Control $1997 ; 6: 14$-8.

15. Cigarette smoking among adults-United States, 1995. MMWR Morb Mortal Wkly Rep $1997 ; 46: 1217-20$.

16. Pierce JP, Fiore MC, Novotny TE, Hatziandreu EJ, Davis RM. Trends in cigarette smoking in the United States. Educational differences are increasing . JAMA $1989 ; 261: 56-60$.

17. Shaikh MA, Kamal A. Prevalence and pattern of smoking in university students - perspective from Islamabad. J Coll Physicians Surg Pak 2004; 14: 194

18. Zaman M, Irfan U, Irshad E. Prevalence of cigarette smoking among Peshawar University students. Pak J Chest Med 2002; 8: 9-18.

19. Pierce JP, Fiore MC, Novotny TE, Hatziandreu EJ, Davis RM. Trends in cigarette smoking in the United States. Projections to the year 2000. JAMA $1989 ; 261: 61-5$.

20. Novotny TE, Fiore MC, Hatziandreu EJ, Giovino GA, Mills SL, Pierce JP. Trends in smoking by age and sex, United States, 1974-1987: the implications for disease impact. Prev Med $1990 ; 19: 552-61$.

21. Grunberg NE, Winders SE, Wewers ME. Gender differences in tobacco use. Health Psychol $1991 ; 10: 143-53$.

22. World Health Organization. The tobacco epidemic: a global public health emergency. Tobacco Alert. April 1998. Http://www.who.int/archives/tobalert/apr96/fulltext.htm .

23. Parkin DM, Pisani P, Lopez AD, Masuyer E. At least one in seven cases of cancer is caused by smoking. Global estimates for 1985. Int J Cancer $1994 ; 59: 494$-504. 
KAP STUDY REGARDING ILL EFFECT OF SMOKING OVER THE HEALTH OF PEOPLE PARTICULARLY ORO-DENTAL HEALTH AND THER PREVENTION

IGMDS

24. Amos $\mathrm{Cl}$, Caporaso NE, Weston A. Host factors in lung cancer risk: a review of interdisciplinary studies. Cancer Epidemiol Biomarkers Prev $1992 ; 1: 505-13$.

25. U.S. Office on Smoking and Health. The health consequences of smoking: nicotine addiction. A report of the Surgeon General. Rockville (MD): [DHHS Publ No. 88-8406], 1988.

26. Pontieri FE, Tanda G, Orzi F, Di Chiara G. Effects of nicotine on the nucleus accumbens and similarity to those of addictive drugs. Nature $1996 ; 382: 255-7$.

LICENSE: JGMDS publishes its articles under a Creative Commons Attribution Non-Commercial Share-Alike license (CC-BY-NC-SA 4.0). COPYRIGHTS: Authors retain the rights without any restrictions to freely download, print, share and disseminate the article for any lawful purpose. It includes scholarly networks such as Research Gate, Google Scholar, LinkedIn, Academia.edu, Twitter, and other academic or professional networking sites. 